\title{
Is Terrorism Becoming an Effective Strategy to Achieve Political Aims?
}

\author{
Nihat Ali Özcan
}

TOBB University of Economics and Technology

\begin{abstract}
Terrorism is the method of changing policies of decision-makers and behaviors of the wider society by instigating fear through violent acts. Terrorism can be categorized based on several criteria, such as political aim, timing, context and the target of the violent acts, as well as tools and tactics. Although terrorism might sometimes show aspects similar to other types of conflict, such as guerilla warfare, urban warfare, irregular warfare, civil war, and insurgency, it is different from them by its reliance on shock in instigating change. Nevertheless, since 9/11 the nature of terrorism has itself changed to some extent. Rather than focusing on symbolic power, the emphasis for terrorist organizations has shifted from the action's symbolic meaning to more calculable consequences, like the territory gained, weapons accrued, the financial damage inflicted and most commonly the number of the dead and the injured. In the future, we may also see shift towards more knowledge-intense strategies as both terrorists and states adapt to current age of knowledge.
\end{abstract}

Keywords: Terrorism, ISIL, jihadism, separatism, drone warfare

\section{Introduction}

Terrorism is a method, intended to change the policies of decision-makers and behaviors of the wider society by instigating fear through violent acts. The most common violent acts used by terrorists are bombing, assassinations, kidnapping, bank robbery, and shootings. Terrorist organizations can use a combination of these acts with certain aims in their mind, such as attrition, intimidation and provocation of the target. ${ }^{1}$

Terrorism can be categorized according to several criteria. The first of these is the political aim. Terrorist organizations have various political aims. Some of them want to carve out a territory, some of them want to establish an independent state, others look for reckoning or revenge and finally some want to compel the decision-makers to change their decisions or policies. A second parameter to consider is timing. When terrorism is used whenever and as much as it is needed, it can be pretty effective. Therefore, terrorism's effectiveness depends on who commits the terrorist act, when and how the act is performed and how strong the arguments are behind the legitimization of the act. More importantly, terrorism's effectiveness ultimately depends on the response of the target. By adding a factor of violence and fear into existing system, terrorism causes a ripple effect in institutions and in the society.

Nihat Ali Özcan, Associate Professor, Department of Political Science and International Relations, TOBB University of Economics and Technology. Email: naozcan@tepav.org.tr.

Andrew H. Kydd and Barbara F. Walter, "The Strategies of Terrorism," International Security 31, no.1 (2006): 49-80. 
If governments, societies or even individuals do not generate an appropriate response to it, then it becomes an effective tool.

\section{Effectiveness of Terrorism}

Terrorism is an effective method in some countries and only under certain conditions. There is an ongoing debate about why kind of countries are more vulnerable to terrorism's affects. For example, it has been argued that democratic countries are more vulnerable to terrorist blackmail, whereas authoritarian countries are less so. In authoritarian countries, terrorism's effect might be diminished due to several reasons. For example, the news about the terrorist act does not find its way to the wider society because the media is restricted. Under such conditions, the terrorist group would not be able to make use of the theatrical and symbolic impact of the terrorist act. Under democratic regimes however, the abundance of media outlets, especially coupled with advanced technologies, would make the government more vulnerable because of the public opinion's inherent impact on the decision making processes in such countries.

Terrorism's effectiveness is also related to power of the government institutions. If institutions are established and fully functioning, if decision making process is swift and efficient then terrorism's effectiveness diminishes.

Another important factor is of course the societal response. If the society as a whole understands the nature of the threat, maintains a healthy, self-protective instinct and is sensible about the precautions and measures taken, it is hard for terrorism to be effective. There is a strong tendency in governments to respond to the terrorist act as forceful as possible to portray its capability and willingness to protect the society. But at the end of the day, government's capability to counteract terrorism is largely influenced by its effectiveness to pursue a winning public relations campaign. Both parties, the government and the terrorist organization, want to give a convincing message to the public. The terrorist organization's message is "the state is weak and is unable to protect you. If you do not give me what I want, I will keep instigating violence and fear, and eventually will achieve control over your behavior." Whereas the state claims it is strong enough to get rid of these organizations and stop their activities and that there is no room for extreme fear. Therefore, to make these messages credible, both parties tend to engage in an excessive show of power. But if the regime is democratic, and rationality prevails, the state response turns to a more proportionate level. In authoritarian regimes however, there is no such reason to convince the society in either way because the public lacks any power to shape policies. Even so, the public can be effectively shielded from the terrorism's wider effect since in terrorists' the most common strategic tools for propaganda and dissemination, communication and media technologies, does not work freely and independently. When the public is not informed, it is not disturbed. For example, it is unlikely for terrorism to be effective in North Korea. In comparison, it can be more effective in France and United Kingdom as it generates an immense societal response and reaction.

Culture and habits also limit terrorism's effectiveness to some extent. When terrorism is naturalized as an ordinary part of everyday life, it becomes less effective in instigating change.

There are also differences in effectiveness, based on the tools and tactics. The attacks which have an element of surprise or shock seem to be the most effective. The surprise 
element is usually dependent on organization's capacity to learn and adapt. Terrorist organizations are learning organizations. They learn from their own experiences or from the experiences of other organizations and movements. ISIL, for example, when you look into their manuals and journals, learns from not only its own past, but from other organizations' past mistakes. Its evolution does not only spring from the wars and conflicts in Iraq and Syria. It also incorporates lessons from Vietnam War, from Soviet-Afghan War of 1979-1989, Algerian War of Independence against the French or from Latin American Revolutionary movements. Whereever there is terrorism, guerilla warfare or any form of irregular warfare, they draw lessons. They do not care whether or not the organization or movement in question is Marxist, capitalist or anything.

Their learning process also incorporates adaptations of techniques developed for other spheres of life. For example, terrorists might include an engineer's hard-work and resourcefulness to build a passenger plane into their terrorist strategy by using that plane not as a vessel but as a flyable bomb. Another example may be artificial fertilizers. A country may invest in buying millions of tons of nitrogen based fertilizers for its agricultural sector. The terrorists may acquire such material, go online and read the scientific article about the use of artificial fertilizers in detonation of open coal mines, and use both technologies to inflict harm.

Of course, terrorist's learning depends on availability of such technologies at the first place. Advancement of technology, especially in transportation and communication enables weak individuals to exert enormous power. In the nineteenth century, dynamites and revolvers were the terrorists' weapons of choice. Today, there is a great range of weapons, which extends from the simplest to nuclear ones, which enhances terrorists' capacity to inflict harm to unprecedented levels. Today we talk about nuclear terrorism, bioterrorism or chemical terrorism. Most of these materials can be acquired by terrorists. This possibility alone greatly enhances terrorists' capacity to instigate fear and terror, hence increasing their effectiveness.

\section{Terrorism and Other Forms of Political Violence}

There is also a difference between terrorism and other forms of political violence with respect to effectiveness. Obviously, guerilla warfare, urban warfare, irregular warfare, civil war, terrorism, insurgency are all different. Nevertheless, terrorism might sometimes show aspects similar to these other types in the course of their campaigns. Terrorism primarily relies on shock to change the minds of decision-makers and to control society. Organizations may choose to rely on terrorism as the main building block of their wider military-political strategy, but they can also incorporate a combination of all these other forms to supplement terrorism and make the whole strategy it more effective. For example, terrorism can start as a tool to kick-start and promote a long-term and wider insurgency as a result of a carefully thought-out plan. Terrorism can be used initially, and can later be discarded, or relocated depending upon the aims of the movement. Therefore, terrorism can increase the effectiveness of the wider strategy by instigating shock and fear.

On the other hand, terrorism is mainly a small-group act and its effects are in accordance. When it is supplemented by guerilla warfare, i.e. some military-like force, the whole campaign turns into a military movement which aims for popular legitimacy. Terrorism, on its own, does not aim for such support because it operates under the assumption that the system can be taken out by single/sudden acts of violence intended for change in certain 
policies and behaviors. This distinction is very important, as in informs counteraction strategies and mechanisms. Terrorism is mainly a criminal act and should be dealt with police force. Terrorists are criminals who must be brought to justice by putting them on trial. In long-term political strategies such as insurgencies, however, the ultimate judge becomes the public itself. Therefore, the main battlefield in insurgencies is the hearts and minds of the people, and the trouble becomes a governance problem, i.e. who will govern?

Let's look at some examples from Turkey. ASALA's (Armenian Secret Army for the Liberation of Armenia ) actions, which ranged from assassinations to a few public attacks, such as the one in Ankara Esenboga Airport in 1982, were mainly criminal acts. The counterstrategy was to gather intelligence on the organization and individuals, apprehend these individuals and bring them to trial. Consider PKK (Kurdistan Worker's Party) on the other hand. PKK has used and currently uses all forms of terrorism. It has been designated as a terrorist organization by many states and institutions. Nevertheless, it also claims to be a guerilla movement and a revolutionary organization with transnational ties. More importantly, it has claims for representation of a particular ethnic group within Turkey's borders, which translates into self-ascription of authority to govern them. Hence, there is a competition between the state and the PKK to govern.

It is also possible to assess terrorism's effectiveness by looking into how much they can achieve their strategic goals. In attrition, the terrorists try erode the state's resolve to fight by showing that they can go on inflicting pain for an indeterminate time. If they seek intimidation, they try to persuade the people that they have to behave as the terrorists wish, whereas in provocation they try to induce emotions leading to indiscriminate violence by the state. Some of the terrorists acts may be more suitable to achieve the above aims. For example, suicide bombing has become an increasingly dreaded terrorist act, due to its frequency.

Due to their political aims, ethnicity-based, or class-based terrorist organizations strive for political legitimacy in the eyes of the public. Therefore, terrorist organizations try to evolve into something different over time, even incorporating some of the modern humanitarian values, a liberal perspective even. For any cause to be legitimate in the public's eye or even for them to begin listening to the message, the organization's general system of values has to be in line with the values of the society. In the course of such evolution to an entity with wider audience, these organizations' range of activities begun to be restricted due to moral hazard. Some limits were established about harming women and children and/or civilians. In that case, targets of terrorist acts become state or government employees, and usually combatant personnel, a change which terrorists would suppose is more tolerable by the public. In other times, for example, the terrorists would call the authorities and tell them about the bombs they planted. The important thing, they would realize, is not how many people they would kill, but how much panic they would cause and hence instigate a public debate about their demands.

\section{Changing Nature of Terrorism}

Pre-9/11 literature defined terrorism as method of symbolic action. Rather than achieving some material/military victory, the terrorist usually aims for a symbolic one. This can only be won if the number of audience is very high, the message is loud and impressive. The emphasis is on the message the act would convey. After the $9 / 11$, the reference point for terrorist acts has increasingly become religious, and interestingly -and perhaps ironically- the emphasis 
has shifted from the action's symbolic meaning to more calculable consequences, like the territory gained, weapons accrued, the financial damage inflicted and most commonly the number of the dead and the injured. While previously, the acts were committed in the name of the wider group that the terrorists claimed to represent, in the new era, the terrorists undertake such acts either in the name of God, and/or for the terrorist himself/herself, because he will go to heaven by doing so. That is perhaps why terrorism has become even more brutal and shocking, devoid of any moral imperative whatsoever. There is no more a concern about the number of civilian casualties or the level harm to women and children, because if the ones who got killed are on the other side, it is supposedly God's wrath on the enemy. If they are accidental deaths, then they would be martyrs, too and go to heaven as well.

The above form of legitimization does not change terrorism into something else, but it shapes its character. The new terrorists are not bound by the type of rationality or value systems that would guide the ethnicity-based terrorism with respect to public sensibilities. Values such as human rights, equality or liberty are considered alien, even evil, because they are perceived to be originating from the 'enemy' or the 'infidel'. The claims and raison d'être of ethnicity-based terrorism on the other hand, is usually based on principles such as self-determination and freedom, all of which originate from the Western system of values. Especially those organizations operating in Western, or Westernized countries, feel the need to justify and modify their actions based on such values, which a makes them susceptible to other values of this system. In the end, if ethnic separatist organizations achieve their aims, the final result would be yet another Western form of political entity. For example even if Irish Republican Army (IRA) manages to obtain full independence in Northern Ireland, the system of values for the new political entity will not be so much different from that of the United Kingdom or from those of the Western civilization for that matter. The newer and more religiously inspired terrorists, however, rely on an entirely different system of values, and their rejection of the Western values is not only total but also accompanied by brutal hostility.

One may assume that such total rejection of values would jeopardize recruitment campaigns of terrorists, shrink their audience, and hence reduce their effectiveness. But actually, it does not. The organizations like ISIL have their own system of meaning, and focus on the opportunity to brutally punish the enemy as their main recruitment message: "I am punishing the infidels, whose way of life you detest. Join me if you want to do the same. " Think about a young man living in France, Germany or Italy, unemployed, feeling downtrodden and excluded, and full of anger and hate. These organizations offer this man tools and methods to express his anger and hate. The organization calls him to action, whether by leaving or staying in the same place, tells him to punish the others and most importantly to instigate fear. Going to heaven comes as a bonus. From their perspective, the logic is simple, understandable and ultimately rational.

\section{Is ISIL successful?}

What is success? If we define success as establishing sovereignty over a piece of land, ISIL has for some time been successful. But we must keep in mind that the "state" they have in mind is very far from the Westphalian state. On another note, ISIL's antagonists are pretty powerful states and if they had wanted to stop it, they would. But is success is defined as going to heaven, then they are ultimately successful, there is no way to defeat them. Whenever they lose worldly battles, they are winning the heavenly struggle to go to heaven. 
Apart from these two definitions of success, I believe, ISIL has been more successful in shaking up the contemporary status quo and in regard to the debate it sparked in the global community. The level of fear and brutality and the atmosphere it has set up, has been far more important than its actual/material impact. The messages they spread, even those that are seemingly mythical and unrealistic are carefully carved out to paint a convincing and deeply relevant picture of a battle between ultimate evil and ultimate good.

ISIL's partial success was also dependent upon its timing. ISIL has not come to the fore until the timing was right and this was a calculated move. Prior to ISIL's dominance, all other organizations in the Syrian War scene had a very severe shortcoming: they had begun to fight before they could come up with a thought-out political agenda. There are three criteria which give out the degree of maturity of the organization. The first one is whether the organization has a clear ideological framework and a clear political agenda which manages its military capacity and shapes it actions. The second is whether the organization has managed to isolate and sometimes take over other similarly organizations competing for the same resources. The initial strategic goal of a terrorist organization is never establishment of a state; it is to eliminate rivals. At this initial stage, elimination happens through absorption and assimilation of other organizations. Highly professional organizations do not engage in direct confrontation until it has become mature enough. ISIL is not unique in waiting until all competition has subsided -this aspect is common to Mao's, Ho Chi Minh's, or Võ Nguyên Giáp's strategy- but it is unique in coming up with a religiously-inspired discourse, combining it with techniques mostly developed by Marxist organizations and doing it at a place where there are two failed states at a time when there is a regional and global power vacuum. Global rivalry and division among regional actors provided the necessary ecosystem for ISIL prominence. There is currently a proxy war going on, but for some time the major powers were oblivious to the region's problems. The US has tried to stay clear of the most pressing tribulations Syrian Civil war posed, whereas Russia was preoccupied with the Ukrainian crisis. That's why ISIL's capture of Mosul in June 2014 was a surprise to regional and global actors: they were not particularly looking. But capturing of Mosul, ISIL has altered the tolerable balance of power, and hence get their attention. Accordingly, ISIL's presence as such will continue as long as the global powers do not come to an agreement. The moment they do, ISIL would have to transform itself, either by retreating underground or splintering over the region and beyond.

There were reasons for such disinterest on the part of Western states, obviously. First of all, the task is extremely difficult. Elimination of an organization like ISIL may not amount to much, because of the high level of mobility and transfer of terrorists from one group to another during civil wars. Even if one is able to reduce their total numbers significantly, their capability to inflict harm remains high due to their abuse of technology. Secondly, the past experiences in Afghanistan and Iraq were particularly discouraging. Thirdly, the material cost of stopping a civil war is huge, almost unbearable. It would probably require 300.000 ground troops stationed over the course of 3-5 years to stop the conflict in Syria and Iraq and re-build both states. The cost would be higher when intervention is done by militaries of advanced, democratic nations, as these armies rely on hi-tech and very costly weapons, surveillance and defense systems. The Western electorate would not tolerate such a huge material cost, let alone human casualties. Finally, there are many concerns regarding the repercussions due to voluntary or involuntary violation of legal and ethical rules in the battlefield. In Western 
democratic states, the free media picks up on these transgressions and the public opinion is already very sensitive. Since the electorate holds decision-makers responsible for such acts, politicians are seldom willing to take such risks.

\section{Counter-terrorism in the New Era}

The turning point for Western interests was the phenomenon of the so-called foreign fighters. When Western citizens who fought alongside ISIL begun to return, the gravity of the issue became clear. The Western countries are still reluctant, though. Obama could only go far as to support the local actors, rather than using conventional military power. The reasons for such choice are manifold.

When the sides of a war are asymmetric, sides do not want to play by the same rules. In mathematical terms, the US is obviously superior with personnel, technology, etc. On the other hand, as usually happens in this type of warfare, weaker player subverts the game, trying to play by different rules. Rather than fighting openly, waiting seems to be optimum strategy for ISIL because they think that the public's resilience in the face of violence in Western democracies is not particularly high. ISIL can wait and fight intermittently, the armies sent from abroad, however, cannot hold for so long because the public would demand results after some time. Secondly, ISIL strikes in extremely unexpected ways. In July 2016 in France, one of them killed several people by driving a truck over them.

To overcome these problems, the states may revert to cooperating with local forces. If anything bad happens, it becomes these local actors' responsibility. If they are victorious, you can be proud. Moreover, training local actors cost very little compared to sending troops. It does not require a big manpower, a few special operations personnel can train many in a short time. A second way other than supporting local actors is to air strikes and unmanned aerial vehicles, PR drones. Real-time intelligence and strike capabilities of these vehicles are probably more effective in failed states and civil wars. The public also demands use of these weapons instead of using actual manpower because they are less risky or presumed to be more effective. One must be cautious though; the terrorists also develop some strategies to counter these capabilities. They live among the civilians and in cities for example. Cities provide enormous resources and opportunities for them. Tunnels, roads, privacy of homes all make the terrain into a maze full of obstacles for security personnel. Furthermore, they can make their own drones, using commercial drones for their purposes.

The terrorism has far reaching repercussions and fighting it has never been easy. But taking into account the democratic pressures and technological advancements, it is reasonable to expect more knowledge-intense strategies to replace traditional counter-terrorism measures. On the technological side, there is a huge research and development ongoing with respect to drones, for example. Many countries invest in developing surveillance and weapons systems, lowering the risk for human lives. The knowledge-intense strategies are not confined to combat or intelligence technologies, either. In response to increasing prominence of terrorism along ethnic and religious lines, states have already begun to train soldiers like cultural anthropologists or sociologists, who can understand and communicate effectively with local people. Combined, these developments signal not only a new age of terrorism, but also a new age for counter-terrorism, as well. 


\section{Bibliography}

Kydd, Andrew H., and Barbara F. Walter. "The Strategies of Terrorism.” International Security 31, no.1 (2006): 49-80. 